\title{
11. Of chainsaws and grace: direct action by eco-vigilantes in the Philippines
}

Bobby Chan

I confiscated my first chainsaw in 1998. Previous to that, I was a fresh law intern from Ateneo de Manila University trying to change the world with Pentel pens and brown manila paper, idealistically educating tribal communities on environmental laws in Palawan, the Philippines' last frontier. That did not work very well. Either people were too poor or corruption was too ingrained. And it felt really hypocritical of me to spend non-governmental organization (NGO) funds on training sessions and workshops, while a stone's throw away, I could hear the hum of a chainsaw and the blasts of dynamite fishing. So, in 1998, I decided to ditch my teaching tools and go after the bumble bees of the forests.

Environmental law enforcement in Palawan, and in the rest of the Philippines for that matter, is archaic. Authorities are either inadequate, inefficient, and more often than not, in cahoots. Statistics from the Department of Environment and Natural Resources reveal that there is one ranger for every 4000 hectares of forest in the nation. In Palawan, the ratio rises to one in 10 000. The Palawan Council for Sustainable Development and the provincial government still believe in guarding the forests via checkpoints where the trees are already dead. And in my neophyte years, I turned over a ton of confiscated items and conveyances to the authorities, only to learn later that they were returned to the violators. Never again, I said to myself.

Any solution should not just be out of the box; it should be radical. I am a Christian who follows the teachings of Christ. And Christ is radical. Jesus whipped the money changers, proclaimed 'blessed are the poor', and resurrected himself to give his disciples burning hearts. I asked myself, how I can be more like Christ?

First, I needed a commandment. A law saying I can do things directly, without going through a corrupted structure. If there is one thing salvific that we got out of copying our laws from the Americans, it's the statute on citizen's arrest. Thanks to this, we were able to conduct community-led confiscations. Naively, we started confiscating illicit timber. But these being both hardwood 
and huge, it became too taxing both physically and financially. So, we set our sights on the chainsaws. And what a glorious result - 50 in the first year.

But like Christ, our efforts were belittled. Some people said we only confronted small carabao-logging ${ }^{1}$ crimes. So, in 2010 and 2011, we seized two large vessels, one loaded with logs destined for Malaysia and another for cyanide fishing destined for China. We also impounded logging trucks, jeepneys, ${ }^{2}$ and tricycles, as well as dynamite-fishing boats and commercial fishing nets infringing on waters earmarked for small fishers. Yet, it is true that no prophet is welcome in his hometown as our critics remain unconvinced. So, in 2013, we thought, maybe if we help them with their fight against mining, they would love us. This we did, hauling two diamond hydraulic drills from the gold mining operations of one of the richest men in the country, in no less than a protected area in the south. Still, we were not accepted.

This revolution did not come without a cost. Twelve dead. Some in the most gruesome ways unimaginable. Roger Majim, prostate cut off and shoved in his mouth, tongue cut off, stabbed several times and full of cigarette burns. 'Tay Albet, shot-gunned at close range on his way to their watershed guard house. Nestor Lubas and Tinde Salamat, ambushed on their motorbike and shot between their eyes to make sure they were dead. Loggers and illegal fishers are armed. And among our confiscated items are an array of long and short firearms with piles of machetes and bolos. ${ }^{3}$ While these deaths should necessarily scare my team, it puzzles me how they turn it into a desire to plan the next operation.

Then there are the harassment lawsuits to contend with. Charges range from robbery, coercion, usurpation of authority and, my favorite, extortion in exchange for non-filing of cases. Two of these cases reached the Supreme Court. Both upheld me and my para-enforcers. Each is its own agony in the garden and a crown of thorns because you do not sleep too well with these lingering at the back of your head. Then after carrying your cross, there is the resurrection. No cases against us have prospered and we have never been incarcerated.

Which brings me to our secret weapon that explains how so much has been achieved by a bunch of farmers, fisherfolk, and tribal people turned para-enforcers. Prayer. And Grace. I was not always a religious person. In fact, my closest epiphany was going to mass to look at girls and joining a Catholic organization to pursue a lady who would soon become my wife. But slowly you learn to listen to a voice inside that tells you what to do; gives you direction; and a peace that surpasses all understanding, because it is rooted in pain and suffering yet results in joy. Does that make sense? Maybe it should not because as I try to define it, it loses its mystery and its weight. The closest I can get is to a Jesuit priest's decoding of being in a state of 'having singularity 
of purpose', where all fear, all doubt, all worry is subsumed, not erased, and everything is in place. Grace.

What we in the environmental movement need to realize is that our affairs should mostly be governed not by doing what is right, but by grace. True power is knowing you can wield it and yet you yield. Compassion. Administer cases so as not to imprison the poor logging helper but to exact a toll on the financier who loses his equipment and conveyance. Grace in controlling situations beyond your control, the weather, your team's health, your adversaries' thoughts and emotions, the influx of funds, and multiplication of bread. All is grace. And everything can be Eucharist.

Whilst my writing might suggest no concrete strategy other than divine intervention, allow me to reconcile it with a more logical mind to promote a change in our way of thinking. Most environmentalists seek recognition. Jesus took a child and set him in their midst. Humility. So, I suggest the following strategies: (1) meet the need for a lawyer for communities; (2) allow civil society more executive powers - for example, to impound equipment; (3) focus on a cultural trait that brings people together for something other than for money or payment, in this case religion; and (4) shift funding from education and research to enforcement and direct action.

I have come to believe the problem that plagues us is not poverty, but pride. Our leaders, and more so, fellow advocates, just have too much pride, and this prevents resources and funds, which are needed to combat environmental violations, from going where they should go or where they are most effective, simply because it will not be them who will be recognized, or it is not their idea. They tend to be Messianic, as though they are the only ones who can save the forests or corals. And in the process end up trying to stop a logger or dynamite fishers by holding a heavily funded environmental education workshop or seminar, while programs like ours beg for gas money and are often put down, ignored or downplayed. We need open-minded policymakers and funding agencies that will support Third World solutions to Third World problems, and not First World remedies that are intellectually stimulating and really look good on paper but have no real effect in the area.

Over two decades and 700 chainsaws later, I'm still here.

\section{NOTES}

1. Carabao-logging is logging in Philippine forests that are inaccessible to trucks and bulldozers due to steep terrain, so the timber has to be ferried out by carabaos into flat or level areas where they can be loaded into trucks.

2. Sometimes called jeeps, jeepneys are buses and the most popular means of public transportation in the Philippines. They are known for their crowded seating and colorful decoration.

3. A bolo is a long knife or machete. 